\title{
ANALISIS FAKTOR YANG MEMENGARUHI KEPATUHAN PERILAKU PENCEGAHAN PENULARAN DAN KEPATUHAN MINUM OBAT PADA PASIEN TUBERKULOSIS PARU BERBASIS TEORI HEALTH BELIEF MODEL
}

\author{
(Factors analysis that Influence Compliance Behavior of Drug Prevention and Drug \\ Compliance on Tuberculosis Patient Based on Health Belief Model Theory)
}

Liliek Juliati, Makhfudli Makhfudli dan Andri Setiya Wahyudi

Fakultas Keperawatan, Universitas Airlangga, Surabaya, Indonesia

\section{RIWAYAT ARTIKEL}

Diterima: 6 Juni 2020

Disetujui: 6 Agustus 2020

\section{KONTAK PENULIS}

Liliek Juliati lilikjuliati76@gmail.com Fakultas Keperawatan, Universitas Airlangga

\begin{abstract}
ABSTRAK
Pendahuluan: Penularan TB dan kegagalan dalam pengobatan dapat berdampak pada sulitnya pemberantasan penyakit TB Paru serta memperberat beban pemerintah dan rawan menyebarluas di masyarakat. Penelitian ini bertujuan menganalisis faktor yang berperan dalam kepatuhan pencegahan penularan dan pengobatan pada pasien TB paru dengan pendekatan teori health believe model.

Metode: Metode penelitian yang digunakan dalam penelitian ini adalah cross sectional dengan 120 responden yang menjalani pengobatan pada fase intensif dan lanjutan. Uji statistik yang digunakan dalam penelitian ini adalah uji multivariat yaitu dengan regresi logistik.

Hasil: Hasil yang ditemukan dalam penelitian ini adalah faktor yang berhubungan dengan kepatuhan pencegahan penularan adalah usia $(0.042 ; 0 \mathrm{R}=4.372)$, persepsi kerentanan $(0.045 ; 0 R=0.289)$, pada kepatuhan pengobatan adalah sosial ekonomi (0.006), persepsi keseriusan $(0.024 ; 0 R=0.109)$, persepsi kerentanan $(0.009 ; 0 R=0.773)$, pendidikan $(0.034 ; \mathrm{OR}=4.674)$.
\end{abstract}

Kesimpulan: Usia dan pendidikan merupakan faktor dominan pada model (HBM) terkait pencegahan penularan dan pengobatan pada TB paru. Diperlukan media pendidikan dalam upaya peningkatan pengetahuan pencegahan dan pengobatan TB Paru.

Kata Kunci

HBM; kepatuhan pencegahan penularan; kepatuhan pengobatan; TB Paru

\section{ABSTRACT}

Introduction: TB transmission and failure in treatment can have an impact on the difficult eradication of pulmonary TB disease and aggravate the burden on the government and prone to spread in the community. This study aims to analyze the factors that play a role in adherence to prevention of transmission and treatment in pulmonary TB patients with a health believe model approach.

Method: The research method used in this study was cross sectional with 120 respondents undergoing treatment in intensive and advanced phases. The statistical test used in this study is a multivariate test namely logistic regression.

Result: The results found in this study are factors related to prevention of transmission prevention are age $(0.042 ; \mathrm{OR}=4.372)$, perception of vulnerability $(0.045 ; \mathrm{OR}=0.289)$, treatment compliance is socioeconomic $(0.006)$, perception of seriousness $(0.024 ; \mathrm{OR}=$ $0.109)$, perception of vulnerability $(0.009 ; \mathrm{OR}=0.773)$, education $(0.034 ; \mathrm{OR}=4,674)$.

Conclusion: Age and education are the dominant factors in the (HBM) model related to prevention of transmission and treatment in pulmonary TB. Educational media is needed in an effort to increase knowledge of pulmonary TB prevention and treatment. 


\author{
Keywords \\ HBM; pulmonary TB; transmission prevention compliance; treatment complance
}

Juliati, L., Makhfudli, M., \& Wahyudi, A. S. (2020). Analisis Faktor yang Memengaruhi Kepatuhan Perilaku Pencegahan Penularan dan Kepatuhan Minum Obat pada Pasien Tuberkulosis Paru Berbasis Teori Health Belief Model. Indonesian J. of Community Health Nurs. J., 5(2), 62-71. Doi: 10.20473/ijchn.v5i2.17694

\section{PENDAHULUAN}

Tuberkulosis paru (TB paru) merupakan masalah kesehatan masyarakat dengan jumlah sepertiga populasi di dunia terinfeksi Mycobacterium tuberculosis. TB paru dapat menular melalui droplet bila orang yang mempunyai penyakit TB paru batuk dan menyebarkan kuman melalui percikan dahak. Hal ini menyebabkan TB paru mudah menular terhadap lingkungan sekitar khususnya keluarga (Sreeramareddy et al, 2013). Hasil penelitian Wampande et al., (2015) pada anak-anak di Uganda bahwa sebanyak $71 \%$ kasus TB paru akibat penularan dari keluarga dan ini menunjukkan rendahnya kesadaran pasien untuk melakukan pencegahan terhadap penularan paru. Penularan TB dapat berdampak pada sulitnya pemberantasan penyakit TB Paru serta memperberat beban pemerintah dan rawan menyebarluas di masyarakat (Depkes, 2015). Salah satu faktor yang memengaruhi perilaku pencegahan adalah pengetahuan. Pengetahuan terkait pencegahan menjadi hal pokok yang harus dimiliki oleh penderita TB paru. Persepsi sebagian masyarakat bahwa penyakit yang dialaminya adalah bukan penyakit bebahaya, melainkan penyakit batuk biasa ternyata berpengaruh pada pada munculnya sikap kurang peduli dari masyarakat terhadap akibat yang didapat (Dewi et al, 2016).

Tuberkulosis diperkirakan masih menyerang 9,6 juta orang dan menyebabkan 1,2 juta kematian (Kementerian Kesehatan RI, 2016). Lebih dari setengah (56\%) penderita TB Paru dunia berada di Asia bagian selatan-timur dan wilayah Pasifik bagian barat. Menurut laporan Global Tuberculosis Report 2018 yang dirilis pada bulan September, Indonesia menempati urutan ke 3 dengan jumlah penderita TB terbanyak setelah India dan Cina, yaitu $10 \%$ dari seluruh penderita di dunia. Pada tahun 2017 ditemukan jumlah kasus tuberkulosis sebanyak 446.732 kasus, dengan rincian kasus sebanyak 321/100.000 penduduk. (WHO, 2018). Prevalensi penduduk Indonesia yang didiagnosis TB paru oleh tenaga kesehatan pada tahun 2018 adalah $0.4 \%$, tidak berbeda dengan 2007 dan 2013 (Badan Penelitian dan Pengembangan Kesehatan, 2018).

Kota Surabaya memiliki kasus TB paru terbanyak pertama di Provinsi Jawa Timur dengan jumlah yaitu 4293 kasus (Dinkes Jatim, 2017). Kematian TB di Kota Surabaya diperkirakan mencapai 10.108 penderita BTA positif (Ministry, 2018). Berdasarkan catatan
Kemenkes RI 2016, angka keberhasilan pengobatan menurun drastis dari tahun-tahun sebelumnya. Sejak tujuh tahun sebelumnya, angka keberhasilan pengobatan berkisar pada 90,1\% hingga 92\%, kemudian menurun menjadi $85 \%$ (data per Juni 2016), angka tersebut masih di bawah target succes rate dari WHO yang menetapkan target > 85\% (Kementerian Kesehatan RI, 2016). Data pada Puskesmas Kedinding Surabaya pada Juli 2019 ditemukan sebanyak 70 orang menderita TB paru dengan kejadian penularan pada keluarga sebanyak 47 orang dan puskesmas Kenjeran ditemukan 63 kasus dengan penularan pada keluarga sebanyak 39 orang. Dilaporkan juga bahwa meskipun seluruh pasien pernah diajarkan cara penularan TB paru akan tetapi hanya 51\% yang dapat menyebutkan cara penularan TB Paru.

Penularan TB paru ke orang lain dapat terjadi melalui droplet penderita TB paru yang dikeluarkannya (Kemenkes RI, 2014). Risiko penularan TB paru setiap tahun di Indonesia dianggap cukup tinggi dan bervariasi antara 1-3\%. Daerah dengan ARTI (Annual Risk Tubercuosis Infection) sebesar $1 \%$ setiap tahun diantara 1000 penduduk, 10 orang akan tertular (Depkes, 2017). Menurut penelitian Jangid et al., (2016) sekitar $28,43 \%$ pasien tidak melakukan apa pun untuk pencegahan TB dalam keluarga, 50,3\% pasien biasa membuang dahak mereka di tempat sampah, tetapi 21,3\% tidak tahu tentang praktik pembuangan dahak. Praktek meludah sembarangan lebih banyak pada wanita $(20 \%)$ daripada pasien pria $(8,3 \%)$, lebih banyak di pedesaan $(15,5 \%)$ daripada di perkotaan pasien $(2,4 \%)$. Pasien menyebarkan kuman ke udara dalam bentuk percikan dahak (droplet nuclei). Sekali batuk dapat menghasilkan sekitar 3000 percikan dahak.

Teori Health Belief Model (HBM) yang diperkenalkan oleh Resenstock tahun 1966. Teori ini merupakan teori perubahan perilaku kesehatan dan model psikologis yang dapat digunakan untuk memprediksi perilaku kesehatan dengan berfokus pada persepsi dan kepercayaan individu terhadap penyakit (Priyoto, 2014). Variabel yang dinilai meliputi keinginan individu untuk menghindari kesakitan, kepercayaan mereka bahwa terdapat usaha agar menghindari penyakit tersebut mengingat dampak yang ditimbulkan adalah membahayakan orang banyak (Alligod, 2014). Tujuan penelitian ini untuk menganalisis faktor yang memengaruhi perilaku pencegahan penularan TB paru. 


\section{METODE}

Pendekatan penelitian ini adalah cross sectional dengan melibatkan 120 responden yang merupakan penderita TB fase intensif dan lanjutan, mampu berkomunikasi dengan bahasa yang sama dengan peneliti dan tanpa adanya penyakit penyerta. Data dianalisis dengan menggunakan regresi logistik. Penelitian ini telah melalui uji etik di Fakultas Keperawatan Universitas Airlangga dengan Nomor Etik 1788-KEPK.

\section{HASIL}

Berdasarkan tabel 1 dapat dilihat bahwa usia terbanyak adalah $>45$ tahun dengan jumlah 58 responden atau $48.3 \%$ sehingga hampir setengah dari total responden yang ada. Berdasarkan jenis kelamin ditemukan jumlah terbanyak adalah perempuan dengan total 75 responden atau $62.5 \%$. Berdasarkan pendidikan jumlah terbanyak adalah pendidikan menengah sebanyak 61 responden atau $58.2 \%$ yang

Tabel 1. Karakteristik demografi responden yang berhubungan dengan pencegahan penularan pasien TB paru dan kepatuhan minum obat $(\mathrm{n}=120)$

\begin{tabular}{|c|c|c|}
\hline Kategori & $\mathbf{F}$ & $\%$ \\
\hline \multicolumn{3}{|l|}{ Usia } \\
\hline 26-35 Tahun & 32 & 26.7 \\
\hline 36-45 Tahun & 30 & 25 \\
\hline$>45$ Tahun & 58 & 48.3 \\
\hline \multicolumn{3}{|l|}{ Jenis Kelamin } \\
\hline Laki-laki & 45 & 37.5 \\
\hline Perempuan & 75 & 62.5 \\
\hline \multicolumn{3}{|l|}{ Pendidikan } \\
\hline Pendidikan Dasar & 59 & 41.8 \\
\hline Pendidikan Menengah & 61 & 58.2 \\
\hline Pendidikan Tinggi & 0 & 0 \\
\hline \multicolumn{3}{|l|}{ Suku } \\
\hline Jawa & 54 & 45 \\
\hline Madura & 64 & 53.3 \\
\hline Batak & 2 & 1.7 \\
\hline \multicolumn{3}{|l|}{ Sosial Ekonomi } \\
\hline$<1 \mathrm{jt}$ & 17 & 14.2 \\
\hline $1-3 \mathrm{jt}$ & 94 & 78.3 \\
\hline$>3 \mathrm{jt}$ & 9 & 7.5 \\
\hline \multicolumn{3}{|l|}{ Persepsi manfaat } \\
\hline Positif & 98 & 81.7 \\
\hline Negatif & 22 & 18.3 \\
\hline \multicolumn{3}{|l|}{ Persepsi hambatan } \\
\hline Positif & 115 & 95.8 \\
\hline Negatif & 5 & 4.2 \\
\hline \multicolumn{3}{|l|}{ Persepsi Keseriusan } \\
\hline Positif & 114 & 95 \\
\hline Negatif & 6 & 5 \\
\hline \multicolumn{3}{|l|}{ Persepsi kerentanan } \\
\hline Positif & 116 & 96.7 \\
\hline Negatif & 4 & 3.3 \\
\hline \multicolumn{3}{|c|}{ Kepatuhan pencegahan penularan } \\
\hline Tinggi & 96 & 80 \\
\hline Rendah & 24 & 20 \\
\hline \multicolumn{3}{|l|}{ Kepatuhan minum obat } \\
\hline Tinggi & 109 & 90.8 \\
\hline Rendah & 11 & 9.2 \\
\hline Total & 120 & 100 \\
\hline
\end{tabular}

terdiri dari SMP dan SMA/SMK. Sebanyak 64 merupakan responden dengan suku madura atau $53.3 \%$. berdasarkan sosial ekonomi ditemukan pendapatn 1-3 jt merupakan responden terbanyak dengan 94 responden atau $78.3 \%$. persepsi manfaat responden sebagian besar positif yaitu 98 responden atau $81.7 \%$. persepsi hambatan yang positif dirasakan oleh 115 responden atau 95.8\%. persepsi keseriusan positif dirasakan oleh 114 responden atau 95\%. Persepsi kerentanan positif dirasakan oleh 116 responden atau 96.7\%. Kepatuhan dalam pencegahan penularan sebagian besar adalah tinggi dengan jumlah 96 responden atau $80 \%$. Kepatuhan dalam pengobatan sebagian besar tinggi dengan jumlah 109 responden.

Berdasarkan tabel 2 dapat dilihat bahwa pada kategori usia kepatuhan pencegahan penularan dan pengobatan yang tinggi terdapat pada usia $>45$ tahun dengan jumlah 51 dan 53 responden. Berdasarkan jenis kelamin ditemukan kepatuhan pencegahan penularan dan pengobatan yang tinggi ada pada jenis kelamin perempuan dengan jumlah 62 dan 70 responden. Berdasarkan pendidikan ditemukan kepatuhan pencegahan penularan dan pengobatan yang tinggi pada pendidikan menengah yaitu 50 dan 59 responden. Pada variabel ras atau suku kepatuhan pencegahan penularan dan pengobatan yang tinggi ditemukan pada suku madura dengan jumlah 50 dan 58 responden. Berdasarkan sosial ekonomi ditemukan kepatuhan pencegahan penularan dan pengobatan yang tinggi ada pada kategori 1-3 jt dengan jumlah responden 75 dan 89 responden. Persepsi manfaat dengan kepatuhan pencegahan penularan dan pengobatan yang tinggi ada pada kategori positif yaitu 77 dan 88 responden. Persepsi hambatan dengan kepatuhan pencegahan penularan dan pengobatan yang tinggi ada pada kategori positif yaitu 93 dan 104 responden. Persepsi keseriusan dengan kepatuhan pencegahan penularan dan pengobatan yang tinggi ada pada kategori postif yaitu 90 dan 104 responden. Persepsi kerentanan dengan kepatuhan pencegahan penularan dan pengobatan yang tinggi ada pada kategori postif yaitu 93 dan 105 responden.

Berdasarkan tabel 3 hasil uji chi square dengan tujuan seleksi kandidat variabel yang akan diukur dengan menggunakan regresi logistik ditemukan variabel yang memenuhi sarat dalam pengujian regresi logistik pada variabel kepatuhan pencegahan penularan adalah usia, persepsi keseriusan dan kerentanan sedangkan pada kepatuhan pengobatan adalah usia, jenis kelamin, pendidikan, sosial ekonomi dan kerentanan. 
Tabel 2. Cross Tab Kepatuhan Pencegahan Penularan Dan Pengobatan Dengan Variabel yang Diukur berhubungan dengan pencegahan penularan pasien TB paru dan kepatuhan minum obat

\begin{tabular}{|c|c|c|c|c|c|c|}
\hline \multirow[t]{2}{*}{ Kategori } & \multicolumn{2}{|c|}{$\begin{array}{c}\text { Kepatuhan pencegahan } \\
\text { penularan }\end{array}$} & \multirow[t]{2}{*}{$\mathbf{N}$} & \multicolumn{2}{|c|}{ Kepatuhan pengobatan } & \multirow[t]{2}{*}{$\mathbf{N}$} \\
\hline & Tinggi & Rendah & & Tinggi & Rendah & \\
\hline \multicolumn{7}{|l|}{ Usia } \\
\hline 26-35 Tahun & 24 & 8 & 32 & 31 & 1 & 32 \\
\hline 36-45 Tahun & 21 & 9 & 30 & 25 & 5 & 30 \\
\hline$>45$ Tahun & 51 & 7 & 58 & 53 & 5 & 58 \\
\hline Total & 96 & 24 & 120 & 109 & 11 & 120 \\
\hline \multicolumn{7}{|l|}{ Jenis Kelamim } \\
\hline Laki-laki & 34 & 11 & 45 & 39 & 6 & 45 \\
\hline Perempuan & 62 & 13 & 75 & 70 & 5 & 75 \\
\hline Total & 96 & 24 & 120 & 109 & 11 & 120 \\
\hline \multicolumn{7}{|l|}{ Pendidikan } \\
\hline Pendidikan Dasar & 46 & 13 & 59 & 50 & 9 & 59 \\
\hline Pendidikan Menengah & 50 & 11 & 61 & 59 & 2 & 61 \\
\hline Pendidikan Tinggi & 0 & 0 & 0 & 0 & 0 & 0 \\
\hline Total & 96 & 24 & 120 & 109 & 11 & 120 \\
\hline \multicolumn{7}{|l|}{ Suku } \\
\hline Jawa & 45 & 9 & 54 & 49 & 5 & 54 \\
\hline Madura & 50 & 14 & 64 & 58 & 6 & 64 \\
\hline Batak & 1 & 1 & 2 & 2 & 0 & 2 \\
\hline Total & 96 & 24 & 120 & 109 & 11 & 120 \\
\hline \multicolumn{7}{|l|}{ Sosial ekonomi } \\
\hline$<1 \mathrm{jt}$ & 13 & 4 & 17 & 11 & 6 & 17 \\
\hline $1-3 \mathrm{jt}$ & 75 & 19 & 94 & 89 & 5 & 94 \\
\hline$>3 \mathrm{jt}$ & 8 & 1 & 9 & 9 & 0 & 9 \\
\hline Total & 96 & 24 & 120 & 109 & 11 & 120 \\
\hline \multicolumn{7}{|l|}{ Persepsi manfaat } \\
\hline Positif & 77 & 21 & 98 & 88 & 10 & 98 \\
\hline Negatif & 19 & 3 & 22 & 21 & 1 & 22 \\
\hline Total & 96 & 24 & 120 & 109 & 11 & 120 \\
\hline \multicolumn{7}{|l|}{ Persepsi hambatan } \\
\hline Positif & 93 & 22 & 115 & 104 & 11 & 115 \\
\hline Negatif & 3 & 2 & 5 & 5 & 0 & 5 \\
\hline Total & 96 & 24 & 120 & 109 & 11 & 120 \\
\hline \multicolumn{7}{|l|}{ Persepsi keseriusan } \\
\hline Positif & 90 & 24 & 114 & 104 & 10 & 114 \\
\hline Negatif & 6 & 0 & 6 & 5 & 1 & 6 \\
\hline Total & 96 & 24 & 120 & 109 & 11 & 120 \\
\hline \multicolumn{7}{|l|}{ Perspsi kerentanan } \\
\hline Positif & 93 & 23 & 116 & 105 & 11 & 116 \\
\hline Negatif & 3 & 1 & 4 & 4 & 0 & 4 \\
\hline Total & 96 & 24 & 120 & 109 & 11 & 120 \\
\hline
\end{tabular}

Tabel 3. Hasil uji chi square yang berhubungan dengan pencegahan penularan pasien TB paru dan kepatuhan minum obat

\begin{tabular}{lcc}
\hline \multicolumn{1}{c}{ Variabel yang diukur } & $\begin{array}{c}\text { Kepatuhan pencegahan penularan } \\
\text { (p value })\end{array}$ & $\begin{array}{c}\text { Kepatuhan pengobatan } \\
\text { ( } \boldsymbol{p} \text { value })\end{array}$ \\
\hline Usia & 0.098 & 0.178 \\
Jenis Kelamin & 0.346 & 0.220 \\
Pendidikan & 0.584 & 0.023 \\
Suku/ ras & 0.440 & 0.902 \\
Sosial ekonomi & 0.748 & 0.000 \\
Persepsi manfaat & 0.409 & 0.012 \\
Perspsi hambatan & 0.040 & 0.000 \\
Persepsi keseriusan & 0.274 & 0.001 \\
Persepsi kerentanan & 0.011 & 0.288 \\
\hline
\end{tabular}

Berdasarkan tabel 4 ditemukan 2 variabel yang berhubungan dengan kepatuhan pencegahan penularan pada pasien dengan TBC. Diketahui bahwa ada hubungan pada usia dengan kategori $>45$ tahun dengan kepatuhan pencegahan penularan dengan OR
3.324 yang artinya usia pada kategori tersebut 3.324 kali lebih patuh dalam pencegahan penularan. Persepsi kerentanan positif ditemukan lebih patuh 0.39 kali dibanding yang negatif. 
Tabel 4. Model uji regresi logistik pada kepatuhan pencegahan penularan di puskemas

\begin{tabular}{|c|c|c|c|c|}
\hline \multirow{2}{*}{ Variabel yang diukur } & \multirow{2}{*}{ sig } & \multirow{2}{*}{$\operatorname{Exp}(B)$} & \multicolumn{2}{|c|}{ 95\% C.I.for EXP(B) } \\
\hline & & & Upper & Lower \\
\hline Usia & 0.101 & & & \\
\hline Usia(1) & 0.112 & 1.407 & 0.463 & 4.278 \\
\hline Usia(2) & 0.042 & 1.329 & 0.404 & 4.372 \\
\hline Jeniskelamin(1) & 0.074 & 2.019 & 0.734 & 5.553 \\
\hline pendidikan(1) & 0.435 & 0.683 & 0.262 & 1.778 \\
\hline Sosialekonomi & 0.844 & & & \\
\hline sosialekonomi(1) & 0.597 & 2.057 & 0.142 & 29.791 \\
\hline sosialekonomi(2) & 0.563 & 2.003 & 0.191 & 21.039 \\
\hline Rasatausuku & 0.481 & & & \\
\hline rasatausuku(1) & 0.226 & 0.159 & 0.008 & 3.122 \\
\hline rasatausuku(2) & 0.255 & 0.177 & 0.009 & 3.489 \\
\hline persepsimanfaat(1) & 0.558 & 0.665 & 0.169 & 2.611 \\
\hline persepsihambatan(1) & & 0.318 & 0.095 & 1.064 \\
\hline persepsikeseriusan(1) & 0.449 & 0.778 & 0.276 & 2.189 \\
\hline persepsikerentanan(1) & 0.045 & 0.289 & 0.102 & .818 \\
\hline
\end{tabular}

Tabel 5. Model uji regresi logistik pada kepatuhan kepatuhan pengobatan di puskemas

\begin{tabular}{|c|c|c|c|c|}
\hline \multirow{2}{*}{ Variabel yang diukur } & \multirow{2}{*}{$s i g$} & \multirow{2}{*}{$\operatorname{Exp}(B)$} & \multicolumn{2}{|c|}{ 95\% C.I.for EXP(B) } \\
\hline & & & Lower & Upper \\
\hline Usia (1) & 0.385 & & & \\
\hline Usia (2) & 0.432 & 0.391 & 0.037 & 4.073 \\
\hline Usia (3) & 0.397 & 2.002 & 0.402 & 9.975 \\
\hline Jenis kelamin (1) & .981 & & & \\
\hline Sosial ekonomi (1) & 0.006 & & & \\
\hline Sosial ekonomi (2) & 0.999 & 0.432 & 0.000 & \\
\hline Sosial ekonomi (3) & 0.999 & 0.467 & 0.000 & \\
\hline Pendidikan (2) & 0.034 & 4.674 & 0.815 & 26.823 \\
\hline Rasatausuku & 0.999 & & & \\
\hline rasatausuku(1) & 0.989 & .000 & & \\
\hline rasatausuku(2) & 0.986 & .000 & & \\
\hline persepsimanfaat(1) & 0.967 & .000 & & \\
\hline persepsihambatan(1) & 0.966 & .000 & & \\
\hline persepsikeseriusan(1) & 0.024 & 0.109 & 0.008 & 1.456 \\
\hline persepsikerentanan(1) & 0.009 & 0.773 & 0.060 & 1.132. \\
\hline
\end{tabular}

Berdasarkan tabel 5 ditemukan variabel yang berpengaruh terhadap kepatuhan pengobatan yaitu Sosial ekonomi, pendidikan, persepsi kerentanan dan persepsi keseriusan. Sosial ekonomi dengan kategori $<1$ jt berhubungan secara signifikan. Pendidikan menengah yaitu SMP dan SMA berhubungan secara signifikan dan 4.674 kali lebih patuh dibanding dengan pendidikan yang lain. Persepsi keseriusan memiliki hubungan dengan OR 0.109 dan persepsi kerentanan berhubungan dengan OR 0.773 .

\section{PEMBAHASAN}

Hubungan usia dengan kepatuhan pencegahan penularan dan pengobatan

Hasil uji multivariat ditemukan adanya hubungan antara usia dengan kepatuhan pencegahan penularan. Hal ini tidak sesuai dengan penelitian Elisa et al.,(2013) yang menyatakan bahwa tidak ada hubungan antara usia dengan kepatuhan dalam pecegahan penularan TB paru dalam keluarga. Akan tetapi temuan penelitian ini sesuai dengan penelitian Maulana et al.,(2015) bahwa ada hubungan yang kuat antara usia dengan perilaku pencegahan penularan pada pasien dengan penyakit menular.
Responden dalam penelitian ini sebagian besar adalah berumur diatas $>45$ tahun dengan pengalaman dan kemampuan problem solving yang baik tentunya sehingga dalam mengatasi penyakitnya cenderung memikirkan sekitarnya agar tidak tertular terutama keluarga. Robert et al.,(2019) menyatakan bahwa usia menandakan kematangan dalam berpikir berdasarkan pengalaman dimasa lampau. Usia secara eksplisit mengandung makna bahwa sesorang telah mencapai kematangan sel atau organ tubuh pada kondisi tertentu sehingga memungkinkan seseorang mampu mengambil keputusan dengan tepat atas apa yang menimpa dirinya.

Berbanding terbalik pada kepatuhan pengobatan. Variabel usia tidak berhubungan dengan kepatuhan pencegahan penularan. Usia merupakan salah satu variabel yang tidak berhubungan dikarenakan seluruh pasien TB maupun TB MDR disemua umur dapat memiliki perilaku yang sama untuk mencapai kesembuhannya dengan selalu makan makanan bergizi dan juga selalu meminum obat dengan teratur (Lagoa et al.,2015).

Hasil penelitian menunjukkan bahwa sebagian besar responden berusia diatas 45 tahun yang 
berpikir bahwa setelah tidak ada gejala maka berhenti berobat karena merasa sudah sembuh. Kepercayaan inilah yang memungkinkan bahwa usia tidak mempengaruhi kepatuhan pengobatan.

\section{Hubungan jenis kelamin dengan kepatuhan pencegahan penularan dan pengobatan}

Jenis kelamin secara multivariat tidak behubungan dengan kepatuhan pencegahan penularan dan pengobatan. Penelitian yang dilakukan Rose et al.,(2019) menemukan bahwa tidak ada perbedaan kepatuhan pengobatan pada pasien TB paru berdasarkan jenis kelamin. Penelitian ini sejalan dengan penelitian Mulyono di Kalimantan Selatan yang menunjukkan bahwa tidak ada hubungan yang jelas antara kejadian TB MDR dengan jenis kelamin. Beberapa studi menunjukkan laki-laki faktor resiko TB paru lebih besar dengan alasan wanita lebih disiplin dalam minum obat. Sedangkan studi lain mengatakan wanita lebih rentan terjadi TB MDR karena sering datang terlambat dan memiliki perasaan malu dan takut dikucilkan oleh keluarga dan lingkungan sekitar. Sebagian besar responden pada penelitian ini adalah perempuan yang sehari hari bekerja dirumah sebagai ibu rumah tangga.

Erawatyningsih (2009), menyebutkan bahwa wanita adalah berkemungkinan lebih rentan terkena penyakit TB paru, karena beban kerja mereka yang berat, berkombinasi dengan kurangnya mobilitas dan sumber daya finansial. Secara epidemiologi dibuktikan terdapat perbedaan jenis kelamin antara laki-laki dan perempuan dalam hal prevalensi infeksi, progresitiv penyakit, insiden dan kematian akibat TB. Perkembangan penyakit juga mempunyai perbedaan antara laki-laki dan perempuan yaitu pada perempuan penyakitnya lebih berat pada saat datang ke Rumah Sakit. Perempuan lebih sering terlambat datang kesarana pelayanan kesehatan di bandingkan dengan laki- laki. Hal ini mungkin lebih sering berhubungan dengan aib dan rasa malu dirasakan oleh perempuan dibandingkan dengan laki-laki. Perempuan juga lebih sering mengalami kekuatiran akan dikucilkan dari keluarga dan lingkungan akibat penyakitnya. Hambatan ekonomi dan faktor sosio-ekonomi kultural turut berperan termasuk pemahaman tentang penyakit TB paru (Syafrizal, 2008). WHO melaporkan bahwa setiap tahunnya penderita TB paru lebih banyak pada lakilaki dibandingkan dengan perempuan. Secara umum perbandingan antara perempuan dan laki-laki berkisar 1/1,5 - 2,1. Kebanyakan terjadi di negara miskin, dilaporkan $2 / 3$ kasus Tb terjadi pada lakilaki dan $1 / 3$ terjadi pada perempuan. Perempuan lebih banyak melaporkan gejala penyakitnya dan berkonsultasi dengan dokter karena perempuan cenderung memiliki perilaku yang lebih tekun dari pada laki-laki. Responden yang umumnya kaum ibu yang berdagang baik di rumah atau di pasar,mereka malu untuk memakai masker karena takut di jauhi di lingkungan masyarakat dan daganganya menjadi tidak laku. Jenis kelamin tidak berhubungan dengan kepatuhan minum obat, responden yang kebanyakkan $75 \%$ perempuan cenderung malas dan malu untuk berobat, karena mereka menganggap hanya sakit batuk biasa nanti akan sembuh sendiri tanpa di obati.

\section{Hubungan pendidikan dengan kepatuhan pencegahan penularan dan pengobatan}

Berdasarkan pendidikan tidak ditemukan hubungan dengan kepatuhan pencegahan penularan akan tetapi ditemukan hubungan dengan keptuhan dalam pengobatan. Temuan penelitian ini sam dengan penelitian oleh Stuart et al., (2011) bahwa tidak ada hubungan yang bermakna antara pendidikan dengan kepatuhan dalam pencegahan.

Sebagian besar responden berpendidikan menengah yang terbagi atas SMP dan SMA yang secara garis besar adalah responden yang memiliki kemampuan pengetahuan yang baik. Hal ini karena responden / penderita yang mempunyai pengetahuan baik tersebut ditunjang oleh tingkat pendidikan yang tinggi sehingga mereka mengerti benar tentang bahaya penyakit TB Paru dan pada akhirnya akan cenderung berperilaku patuh berobat demi kesembuhan penyakitnya. Pengetahuan tentang penyakit TB dan kepercayaan tentang kemampuan pengobatan akan mempengaruhi penderita mau atau tidak memilih untuk menyelesaikan pengobatannya. Selain itu, kepercayaan kultural biasanya mendukung penggunaan penyembuhan tradisional. Pengetahuan (knowledge) sangat penting peranannya pada penderita TB paru karena dengan mengetahui, memahami tentang pengobatan dan penyakit TB paru serta efek samping, resiko secara teratur. Apabila penderita sudah memahami tentang keteraturan minum obat TB paru secara benar maka penderita akan mengaplikasikan pengetahuan tersebut melalui sikap yang positif. Rifqatussa'adah (2008) mengatakan bahwa adanya pengetahuan yang baik akan mempengaruhi penderita TB paru untuk dapat melakukan sesuatu dengan teratur sehingga dapat mempengaruhi perilakunya. Semakin baik pengetahuan tentang cara minum obat secara teratur, maka penderitta semakin meningkatkan keteraturan minum obat dan pada akhirnya akan cenderung berperilaku patuh berobat demi kesembuhan penyakitnya.

Pengetahuan yang baik akan memunculkan sikap untuk bereaksi terhadap objek dengan menerima, memberikan respon, menghargai dan membahasnya dengan orang lain dan mengajak untuk mempengaruhi atau menganjurkan orang lain merespon terhadap apa yang telah diyakininya. (Notoatmodjo, 2007). Peran serta petugas kesehatan dan PMO bagi penderita TB paru sangat berperan penting dalam keteraturan minum obat. Dengan mengetahui dan menyadari peran PMO dalam proses penyembuhan penyakitnya, maka penderita TB paru akan memberikan respon dan sikap yang positif untuk minum obat secara teratur demi kesembuhan penyakitnya, dengan minum obat secara teratur penderita akan terhindar dari resiko resistensi yaitu penderita gagal menjalankan pengobatan dan akan 
kembali berobat dari awal pengobatan, sehingga akan membuat jangka waktu pengobatan lebih lama dan dengan terapi pengobatan yang lebih dari terapi pengobatan awal, selain resiko penularan kepada keluarga atau orang terdekat yang sering ditemui penderita.

\section{Hubungan ras atau suku dengan kepatuhan pencegahan penularan dan pengobatan}

Pada temuan penelitian ini tidak ada hubungan antara ras atau suku dengan kepatuhan pencegahan penularan dan pengobatan. Hal ini sesuai dengan penelitian oleh Jennifer et al.,(2013) yang menemukan tidak ada perbedaan kepatuhan antara suku jawa dan madura dalam hal kepatuhan minum obat pada pasien TB. Ras atau suku merupakan labeling yang ditentukan karena adanya kesamaan dalam kelompok tertentu sehingga membentuk komunitas tersendiri. Hal ini memungkinkan munculnya kebiasaan dimasyarakat yang berpengaruh terhadap kesehatan. Beberapa ras atau suku di dunia menganggap penyakit adalah kutukan dan harus disembuhkan dengan ritual tertentu dengan tujuan mengusir roh jahat atau penyakit yaang diderita seseorang dari ras atau suku mereka (Videl et al.,2010).

Ras atau suku merupakan pembeda antara budaya dan kebiasaan masyarakat setempat. Suku madura dan jawa cenderung memiliki kemiripan dalam hal kebudayaan atau kebiasaan. Dalam upaya penanganan penyakit ada yang terbiasa dengan pergi ke orang pintar terlebih dahulu kemudian baru ke dokter atau puskesmas, kesamaan inilah yang memungkinkan tidak adanya pengaruh pada kepatuhan pencegahan dan pengobatan pasien TB. Responden yang sebagian besar orang madura dengan jumlah 64 orang, mereka menganggap bahwa sakitnya tidak menular,bahkan ada beberapa responden yang sengaja tidak mau memakai dengan alasan tidak enak,merasa tambah sesak,malu dengan orang lain. Suku juga tidak ada hubungannya dengan kepatuhan minum obat,responden yang mengeluh batuk tidak sembuh-sembuh, biasanya minum jamu atau obat yang di jual bebas terlebih dulu setelah parah baru periksa ke pelayanan kesehatan. Responden menggangap bahwa penyakit adalah dari Tuhan, dan Tuhan akan memberikan obatnya ,setelah merasa lebih baik dari sakit batuknya mereka anggap sudah sembuh dari sakit TB nya.

\section{Hubungan sosial ekonomi dengan kepatuhan pencegahan penularan dan pengobatan}

Berdasarkan uji multivariat tidak ditemukan hubungan antara sosial ekonomi dengan kepatuhan pencegahan penularan akan tetapi ada hubungan dengan kepatuhan pengobatan. Penelitian ini sejalan dengan penelitian Dwi et al.,(2012) di Balai Pengobatan Penyakit Paru- paru Purwokerto yang menunjukkan bahwa tidak ada hubungan antara pendapatan dengan faktor resiko kejadian TB paru.

Sosial ekonomi dalam hal ini lebih pada pendapatan responden dalam keluarga yang diukur dengan nilai uang. Pada penelitian Mariysa et al.,
(2009) ditemukan adanya hubungan antara sosial ekonmi dengan kepatuhan dalam pengobatan. Responden dengan sosial ekonomi rendah cenderung tidak patuh menjalani pengobatan dikarenakan biaya yang diperlukan untuk membeli obat dan transportasi ke puskesmas.

Sebagian besar responden adalah berdagang dengan pendapatan 1.5 juta perbulan yaitu dengan memiliki banyak anak yang perlu di biayai, sehingga responden hanya mampu tinggal di tempat yang ukurannya kecil dan kurangnya ventilasi udara sehingga sinar matahari tidak dapat masuk ke ruangan rumah. Hal tersebut yang mengakibatkan pencegahan penularan jadi terhambat. Dengan pendapatan rendah dimungkinkan daya beli masker rendah jadi lebih memilih tidak menggunakan masker,sehingga resiko penularan ke orang lain sangat tinggi. Hal ini berbanding terbalik dengan kepatuhan Pengobatan TB, responden dengan pendapatan ekonomi yang rendah sangat antusias dalam berobat, karena saat ini pengobatan TB adalah gratis program pemerintah sampai tuntas sehingga tidak perlu memikirkan biaya pengobatan yang dibebankan pada pasien.

\section{Hubungan persepsi manfaat dengan kepatuhan pencegahan dan pengobatan}

Pada penelitian ini tidak ditemukan hubungan antara persepsi manfaat dengan kepatuhan pencegahan penularan dan pengobatan pasien TB paru. Hal ini tidak sesuai dengan penelitian Dady (2017) yang mana pada penelitiannya menunjukkan bahwa persepsi manfaat (perceived benefits) yang dirasakan oleh pasien pada kategori postif mempengaruhi kepatuhan dalam pengobatan dan pencegahan penularan pasien TB paru, yang ditunjukkan dengan pasien percaya jika melakukan pengobatan TB Paru secara rutin, manfaat yang diperoleh adalah penyakit TB Paru akan cepat sembuh. Penelitian lainnya oleh Rahardjo \& Murti, (2017) menyebutkan di Surakarta yang melaporkan bahwa terdapat hubungan antara persepsi manfaat yang dirasakan dengan kepatuhan minum obat. Hal tersebut juga didukung oleh penelitian dari (Horne et al., 2013) yang melaporkan bahwa pasien yang memiliki belief dalam masa terapi akan memberikan pengaruh positif kepada dirinya sendiri. Seseorang yang memiliki persepsi manfaat yang tinggi akan menyingkirkan rasa hambatan atau rasa susah dan tidak enak di dalam dirinya. Penelitian ini juga sejalan dengan penelitian dari (Gerais, 2017) yang menunjukkan bahwa persepsi manfaat yang dirasakan bisa dibangun dengan cara komunikasi terapeutik yang baik antara petugas kesehatan dan pasien.

Perceived Benefits adalah kepercayaan terhadap keuntungan dari metode yang disarankan untuk mengurangi risiko penyakit. Perceived benefits secara ringkas berarti persepsi keuntungan yang memiliki hubungan positif dengan perilaku sehat. Individu yang sadar akan keuntungan deteksi dini akan terus melakukan perilaku sehat seperti medical check up rutin. Manfaat pengobatan yang dirasakan, 
yang berkaitan dengan kepercayaan akan efektivitas berbagai tindakan dalam mengurangi ancaman penyakit (Kangmennaang et al., 2017).

Health Belief Model menjelaskan perubahan dan pemeliharaan perilaku kesehatan sebagai petunjuk cara kerja dari perilaku kesehatan yang meliputi persepsi individu, faktor-faktor yang berpengaruh dan kemungkinan untuk bertindak.

\section{Hubungan persepsi hambatan dengan kepatuhan} pencegahan penularan dan pengobatan

Penelitian ini tidak menemukan hubungan antara persepsi hambatan dengan kepatuhan pencegahan penularan dan pengobatan. Perceived barriers adalah kepercayaan mengenai harga dari perilaku yang dilakukan. Perceived barriers secara singkat berarti persepsi hambatan atau persepsi menurunnya kenyamanan saat meninggalkan perilaku tidak sehat.

Hubungan perceived barriers dengan perilaku sehat adalah negatif. Jika persepsi hambatan terhadap perilaku sehat tinggi maka perilaku sehat tidak akan dilakukan. Semacam analisis biaya-manfaat yang terjadi ketika individu mengetahui hambatan yang dirasakan lebih mahal daripada manfaat yang dirasakan. Kemudian, mereka mengambil tindakan untuk melakukan skrining. Misalnya, penghalang ini

bisa mahal, tersita waktu, tidak menyenangkan, menyakitkan, atau menjengkelkan. Hambatan ini bisa membuat seseorang menjauh dari melakukan tindakan sehat.

Penelitian ini tidak didukung oleh penelitian dari (Rahardjo \& Murti, 2017) yang menunjukkan bahwa

terdapat hubungan antara persepsi hambatan yang

dirasakan pasien dengan kepatuhan berobat pada

pasien TB paru di Surakarta. Hambatan yang dirasakan oleh individu, mempengaruhi seseorang

untuk tidak selesai melakukan terapi pengobatan TB paru. Hal ini juga didukung oleh penelitian dari (Boru,

Shimels, \& Bilal, 2017) yang menyatakan bahwa hambatan yang dirasakan dapat menurunkan tingkat kepatuhan pasien dalam pengobatan TB Paru.

Hambatan yang biasanya dirasakan adalah finansial dan sosial. Ketika pasien memiliki belief terhadap kemampuan dirinya, maka hambatan-hambatan yang dirasakan akan berkurang dan kepatuhan terhadap terapi akan meningkat. Hal ini juga didukung oleh penelitian (Shringarpure, Isaakidis, Sagili, Baxi, \& Das, 2016) yang menunjukkan bahwa kondisi lokasi geografis juga mempengaruhi kepatuhan pasien dalam pengobatan TB Paru, seperti misalnya kondisi jalan yang buruk, serta lokasi fasilitas pelayanan kesehatan yang jauh sehingga membuat seseorang jadi malas berobat. Hal tersebut berbanding terbalik tidak ada persepsi hambatan pada responden karena responden merasa kondisi dirinya saat ini baik- baik

\section{Hubungan kepatuhan pengobatan \\ persepsi keseriusan dengan pencegahan penularan dan}

Persepsi keseriusan berhubungan dengan kepatuhan pengobatan dan tidak berhubungan dengan

kepatuhan pencegahan penularan Persepsi keseriusan maupun ancaman yang dirasakan oleh individu akan mempengaruhi individu tersebut dalam bertindak. Perceived seriousness adalah kepercayaan subyektif individu dalam penyebaran penyakit disebabkan oleh perilaku atau percaya seberapa berbahayanya penyakit sehingga menghindari perilaku tidak sehat agar tidak sakit. Hal ini berarti perceived seriousness berprinsip pada persepsi keparahan yang akan diterima individu.

Perceived seriousness juga memiliki hubungan yang positif dengan perilaku sehat. Jika persepsi keparahan individu tinggi maka ia akan berperilaku sehat (Li et al., 2015). Hal ini sejalan dengan penelitian dari (Rahardjo \& Murti, 2017) yang menunjukkan bahwa terdapat hubungan yang positif antara persepsi keseriusan dan ancaman yang dirasakan terhadap kepatuhan terapi pada pasien TB paru. Tindakan individu untuk mencari pengobatan ataupun mencegah penyakit didasarkan pada separah apa penyakit yang individu tersebut rasakan. Dengan kata lain, semakin tinggi risiko suatu penyakit, maka individu akan mempunyai persepsi yang semakin membutuhkan pengobatan. Hal tersebut berbanding terbalik dengan persepsi keseriusan responden ,dimana responden mengetahui akan bahaya penyakit TB paru,tetapi sebagian besar responden malas memakai masker sebagai salah satu cara bentuk pencegahan penularan, dengan berbagai macam alasan di antaranya : malu, takut di kucilkan, nafas tambah sesak, rasa tidak enak dan lainnya. Sedangkan persepsi keseriusan responden terhadap kepatuhan pengobatan sangat kuat, hal ini terjadi karena responden merasa bahwa penyakit TB paru adalah

penyakit yang serius dan berbahaya, jika tidak melakukan pengobatan secara rutin, maka penyakitnya akan bertambah parah dan penyembuhan penyakitnya bertambah lama.

\section{Hubungan persepsi kerentanan dengan kepatuhan pencegahan penularan dan pengobatan}

Persepsi kerentanan berhubungan dengan kepatuhan dalam pencegahan penularan dan pengobatan. Hasil penelitian ini mendukung penelitian dari Huchko et al bahwa ada hubungan yang signifikan antara persepsi kerentanan dengan keinginan untuk melakukan pengobatan pada pasien TB MDR. Hasil penelitian ini didukung oleh Wiwin et al., (2015) bahwa tujuan 
saja,sakit batuk yang lama bukanlah sakit yang berat nanti akan hilang dengan sendirinya. Begitu pula persepsi responden terhadap pengobatan, meskipun sudah diberikan fasilitas pengobatan secara gratis dari pemerintah, tetapi responden malas untuk berobat dan merasa membuang buang waktu jika melakukan pengobatan secara rutin. sesorang melakukan pengobatan salah satunya adalah agar terhindar dari komplikasi TB atau takut pada bertambah buruknya penyakit. Kemudian dalam (Bakhtari et al., 2012 ) menyatakan bahwa seorang individu akan mengambil tindakan untuk melindungi diri mereka jika mereka menganggap bahwa kondisi mereka rentan terhadap kondisi atau

http://e-journal.unair.ac.id/IJCHN| 69 


\section{JULIATI ET AL.}

masalah yang serius. Rosenstock et al., (1988) menyebutkan bahwa HBM merupakan salah satu model tertua membahas kesiapan untuk melakukan perilaku sehat berdasarkan beberapa keyakinan atau persepsi individu. Hasil analisis menunjukkan bahwa ada hubungan tidak langsung antara persepsi kerentanan dengan kejadian TB paru melalui variabel kepatuhan pasien dalam minum obat tuberkulosis. Hubungan langsung antara persepsi kerentanan dengan kepatuhan minum obat bersifat positif dan signifikan. Hasil penelitian ini sesuai dengan temuan sebelumnya yang menyebutkan bahwa peran keyakinan individu yang pada HBM berpengaruh terhadap keputusan individu dalam meningkatkan perilaku sehat salah satunya yakni kepatuhan dalam minum obat tuberkulosis (Johari et al., 2014; Tola et al., 2016). Persepsi kerentanan responden

berhubungan dengan pencegahan penularan,responden sadar dan mengerti akan penyakitnya berbahaya sehingga responden melakukan tindakan pencegahan penularan di antaranya : memakai masker selama masih dalam pengobatan, jika batuk harus menutup mulut dengan tissue atau sapu tangan, selain itu jika berdahak di buang pada tempat khusus. Begitu pula persepsi kerentanan berhubungan dengan kepatuhan pengobatan, responden yang mengerti akan dampak pengobatan TB yang terputus / tidak tuntas yaitu responden akan mengulang pengobatan dari awal sehingga responden rutin untuk kontrol dan berobat di poli TB agar mendapatkan pengobatan secara gratis dan tuntas serta pemeriksaan dahak secara berkala 2 bulan dan 6 bulan setelah pengobatan.

Penelitian ini memiliki keterbatasan yaitu kuesioner yang digunakan memiliki jumlah pertanyaan yang banyak sehingga responden jenuh pada proses pengisian kuesioner dan terdiri atas berbagai suku sehingga hasil penelitian belum bisa digeneralisasikan untuk suku tertentu.

\section{KESIMPULAN}

Perilaku pencegahan berhubungan dengan usia, pendidikan, persepsi kerentanan, dan persepsi keseriusan dan tidak berhubungan dengan jenis kelamin, ras/suku, sosial ekonomi, persepsi keuntungan dan persepsi kerugian. Kepatuhan minum obat berhubungan dengan sosial ekonomi, dan persepsi kerentanan dan tidak berhubungan dengan usia, jenis kelamin, pendidikan, persepsi keuntungan dan persepsi kerugian. Diharapkan penelitian selanjutnya dapat dilanjutkan dengan mengembangkan model dan modul yang tepat dalam meningkatkan kepatuhan pasien TB paru dalam pencegahan penularan dan minum obat. Pendidikan kesehatan juga sangat diperlukan terkait pencegahan penularan dan pengobatan TB paru dan melakukan pengawasan melalui PMO dan melatih kader kesehatan untuk dapat mendeteksi kejadian TB paru

\section{DAFTAR PUSTAKA}

Ali. (2010). Hubungan Fase Pengobatan TB Dan 70 |
Pengetahuan Tentang Mdr TB Dengan Kepatuhan Pengobatan Pasien TB ( Studi Di Puskesmas Perak Timur ). Jurnal Berkala Epidemiologi, 4(July 2010), 301-312. https://doi.og/10.20473/jbe.v4i3.

Alsagaff, H., \& Mukty, A. (2005). Dasar-dasar ilmu penyakit paru. Surabaya: Airlangga University Press.

Amin, Z., \& Bahar, A. (2009). Ilmu Penyakit Dalam Jilid III (V). Jakarta: Balai Penerbit FK UI.

Badan Penelitian dan Pengembangan Kesehatan. (2013). Riset Kesehatan Dasar (RISKESDAS) 2013. Laporan Nasional 2013, 1-384. https://doi.org/1 Desember 2013

Bols, E., Smits, L., \& Weijenberg, M. (2015). Healthy Living: The European Congress of Epidemiology , 2015. European Journal of Epidemiology, 30(8), 709-1001. https://doi.org/10.1007/s10654-0150072-z

Champion, V., \& Skinner, C. (2008). The Health Belief Model. In Health behavior and health education: theory, research, and practice (p. 613).

Conner, M., \& Norman, P. (2005). Predicting Health Behaviour. (M. Conner \& P. Norman, Eds.) (2nd ed.). New York: Open University Press.

Costa, A., Emmanuel, P., Americano, A., Ramalho, A., \& Cavalcanti, V. (2017). Clinical Nutrition ESPEN Dietary counseling adherence during tuberculosis treatment: A longitudinal study. Clinical Nutrition ESPEN, 17, 44-53. https://doi.org/10.1016/j.clnesp.2016.11.001

Dewi, C., Barclay, L., Passey, M., \& Wilson, S. (2016). Improving knowledge and behaviours related to the cause, transmission and prevention of Tuberculosis and early case detection: a descriptive study of community led Tuberculosis program in Flores, Indonesia. BMC Public Health, 1-12. https://doi.org/10.1186/s12889-0163448-4

Dharma, K. (2011). Metodologi Penelitian Keperawatan: Panduan Melaksanakan dan Menerapkan Hasil Penelitian. Jakarta: Trans Info Media.

Düsing, Rainer, Lottermoser, K., \& Mengden, T. (2001). Compliance to drug therapy - new answer to an old question. Nephrol Dial Transpl.

Glanz, K., \& Rimer, B. K. (2012). Theory at a Glance: A Guide for Health Promotion Practice. National Cancer Institute; U.s. Department of Health and Human Services; National Health (2nd ed.). San Francisco: Create Space Independent Publishing Platform. https://doi.org/10.1128/MCB.25.21.9532

Green LW, Marshall W, K. (1991). Health Promotion Planning An Educational and Environtmental Approach, 506. https://doi.org/10.1016/j.dsr.2004.07.013

Jangid, V. K., Agrawal, N. K., Yadav, G. S., Pandey, S., \& Mathur, B. B. (2016). Health-seeking behavior and social stigma for tuberculosis in tuberculosis patients at a tertiary-care center in North West India, 5(09), 1893-1899. https://doi.org/10.5455/ijmsph.2016.23012016 
371

Jeihooni, A. K., Kaveh, M. H., Hajizadeh, E., \& Askari, A. (2014). The Survey of Osteoporosis Prevention Behaviors in Women Based on Health Belief Model,

https://doi.org/10.18869/acadpub.jrh.7.4.971

Kangmennaang, J., Mkandawire, P., \& Luginaah, I. (2017). Breast cancer screening among women in Namibia: explaining the effect of health insurance coverage and access to information on screening behaviours. Global Health Promotion, O(June), 1757975917727017. https://doi.org/10.1177/1757975917727017

Kemenkes. (2014). Pedoman Nasional Pengendalian Tuberkulosis. (T. Dinihari, Ed.). Jakarta: Kementrian Kesehatan RI.

Kemenkes. (2016). Peraturan Menteri Kesehatan Republik Indonesia Nomor 67 Tahun 2016 tentang Penanggulangan Tuberkulosis. Indonesia: Menteri Kesehatan Republik Indonesia.

Kementerian Kesehatan RI. (2016). Profil Kesehatan Indonesia 2015. (D. Budijanto, Ed.). Kementrian Kesehatan RI. https://doi.org/351.077 Ind

Li, Z. T., Yang, S. S., Zhang, X. X., Fisher, E. B., Tian, B. C., \& Sun, X. Y. (2015). Complex relation among Health Belief Model components in TB prevention and care. Public Health, 129(7), 907-915. https://doi.org/10.1016/j.puhe.2015.04.008

Ministry, R. H. (2018). Hasil Utama Riskesdas 2018. https://doi.org/10.1177/109019817400200403 Notoatmodjo, S. (2012). Promosi Kesehatan dan Perilaku Kesehatan. Jakarta: Rineka Cipta.

Pieter, H. Z., \& Lubis, L. N. (2010). Pengatar Psikologi dalam Keperawatan. Jakarta: Kencana Prenada Media Group.

Price. (2006). Patofisiologi Vol 2 : Konsep Kllinis Proses-proses Penyakit. Jakarta: EGC.

Priyoto. (2014). Teori Sikap dan Perilaku dalam Kesehatan, dilengkapi dengan contoh kuesioner. Yogyakarta: Nuha Medika.

Sabate, E. (2001). WHO Adherence Meeting Report. Geneva: World Health Organization.

Sarwono, S. W. (2012). Psikologi Remaja. Jakarta: PT. Raja Garlindo Persada.

Sreeramareddy, C. T., Kumar, H. N. H., \& Arokiasamy, J. T. (2013). Prevalence of self-reported tuberculosis, knowledge about tuberculosis transmission and its determinants among adults in India : results from a nation-wide crosssectional household survey, 1-9. https://doi.org/10.1186/1471-2334-13-1

Sukartini, T., Sitorus, R., Waluyo, A., \& Darmawan, S. (2015). Adherence in Pulmonary Tuberculosis Patients Based on King's Interacting Systems Theory. Ners Journal, 10, 289-295.

Sukartini, T. (2015) Pengembangan Model Peningkatan Kepatuhan Berbasis Teori Sistem Interaksi King Dan Pengaruhnya Terhadap kepatuhan Pasien Tuberkulosis Paru. Disertasi. FIK UI. Tidak Dipublikasikan.

Sunaryo. (2004). Psikologi Untuk Keperawatan. Jakarta: EGC.
Wampande, E. M., Mupere, E., Jaganath, D., Nsereko, M., Mayanja, H. K., Eisenach, K., ... Joloba, M. L. (2015). Distribution and transmission of Mycobacterium tuberculosis complex lineages among children in. BMC Pediatrics, 4, 1-7. https://doi.org/10.1186/s12887-015-0455-z WHO. (2018). Global Tuberculosis Report (20th ed.). France: WHO Library Cataloguing-in-Publication Data.

Widoyono. (2011). Penyakit Tropis Epidemiologi,Penularan,Pencegahan Dan Pemberantasannya. Jakarta: Erlangga. 